\title{
Is it really an erysipelas?
}

\author{
Muhammed Bekçibaşı1 ${ }^{1}$ illker İnanç Balkan², Ayşe Salihoğlu³, Ali Mert ${ }^{4}$ \\ ${ }^{1}$ Dicle University School of Medicine,Department of Infectious Diseases and Clinical Microbiology, Diyarbakır, Turkey \\ ${ }^{2}$ Istanbul University Cerrahpaşa School of Medicine,Dept. of Infectious Diseases and Clinical Microbiology, İstanbul, Turkey \\ ${ }^{3}$ Istanbul University Cerrahpaşa School of Medicine,Department of Hematology, Istanbul, Turkey \\ ${ }^{4}$ Istanbul Medipol University School of Medicine,Department of Internal Medicine, İstanbul, Turkey
}

\begin{abstract}
Primary cutaneous anaplastic large cell lymphoma is characterized by red-brown plaques or nodules on the skin, may mimic skin and soft tissue infections and is usually related with high mortality. A case that was followed up as complicated erysipelas due to similar clinical findings but diagnosed as primary cutaneous anaplastic large cell lymphoma with histopathological examination has been presented in this report. J Microbiol Infect Dis 2014; 4(4): 168-169
\end{abstract}

Key words: Erysipelas, diffuse anaplastic large cell lymphoma, fever

\section{Bu gerçekten bir erizipel mi?}

\section{ÖZET}

Primer kutanöz anaplastik büyük hücreli lenfoma, deride kırmızı-kahverengi plaklar veya nodüllerle karakterize olup deri-yumuşak doku enfeksiyonlarını taklit edebilmekte ve genellikle yüksek oranda mortaliteyle seyretmektedir. Bu yazıda benzeşen klinik bulguları nedeniyle komplike erizipel ön tanısıyla izlenen ancak histopatolojik inceleme ile primer kutanöz anaplastik büyük hücreli lenfoma tanısı konulan bir olgu sunulmuştur.

Anahtar kelimeler: Erizipel, diffüz anaplastik büyük hücreli lenfoma, ateş

\section{CASE}

A 28 year old female patient was admitted with diffuse erythema, edema and pain on the right thigh emerging six weeks ago and spreading bi-directionally towards the genital and popliteal areas. She described fever for 6 weeks. No trauma or any invasive procedure to the right thigh was defined. She was under immunosuppressive treatment (prednisolone 8-16 mg/day + methotrexate $10 \mathrm{mg} /$ week) for six months due to rheumatoid arthritis. Various antibacterial agents (amoxicillin-clavulanate, ampicillinsulbactam, meropenem, daptomycin, vancomycin) were used for a total duration of 5 weeks in different centers with diagnosis of complicated cellulitis, but she did not respond to any treatment.

In physical examination; the cachectic and exhausted appearance of the patient was remarkable. Her fever was $38.6^{\circ} \mathrm{C}$, arterial pressure $90 / 60 \mathrm{~mm} /$ $\mathrm{Hg}$, respiratory rate $28 / \mathrm{min}$ and heart rate 96 beats/ min. Respiratory sounds were decreased to an inaudible level on the bases of both lungs.

The erythematous, indurated soft tissue lesion (Figure 1) on the right thigh had a shiny dark-red appearance and a sharp demarcation line and there were satellite nodular indurations on the knee. No abscess formation was detected sonographically in subcutaneous deep tissues.

In the laboratory examination; Hgb $8 \mathrm{~g} / \mathrm{dl}$, WBC $12,700 / \mathrm{mm}^{3}$, platelets $60,000 / \mathrm{mm}^{3}, \mathrm{MCV}: 96 \mathrm{fL}$, ESR $6 \mathrm{~mm} / \mathrm{h}$, CRP $101 \mathrm{mg} / \mathrm{L}$, Creatinine $0.4 \mathrm{mg} /$ dl, ALT $10 \mathrm{U} / \mathrm{L}$, AST $66 \mathrm{U} / \mathrm{L}$, Total bilirubine 1.2, and INR 1.4. Arterial blood gas analysis; $\mathrm{pO}_{2}: 71 \mathrm{mmHg}$, $\mathrm{pCO}_{2}: 20 \mathrm{mmHg}$, Lactate: $6 \mathrm{mEq} / \mathrm{L}$. Chest X-Ray revealed bilateral pleural effusion.

In the first hours of admittance, the general medical condition of the patient deteriorated and she was transferred to intensive care unit with noninvasive mechanical ventilation support. Because

Correspondence: Muhammed Bekçibaşı, Dicle University School of Medicine, Department of Infectious Diseases and Clinical Microbiology, Diyarbakır, Turkey_Email: m_bekcibasi@hotmail.com Received: 06 February 2014, Accepted: 08 April 2014 Copyright (C) Journal of Microbiology and Infectious Diseases 2014, All rights reserved 
the clinical picture was compatible with SIRS (Systemic Immune Response Syndrome), imipenem 2 g/day IV + linezolid 1200 mg/day IV was initiated empirically after obtaining blood cultures. Punch biopsy was conducted from the lesion. No bacterial growth was detected in the pleural fluid sample and cytological assessment yielded no pathology.

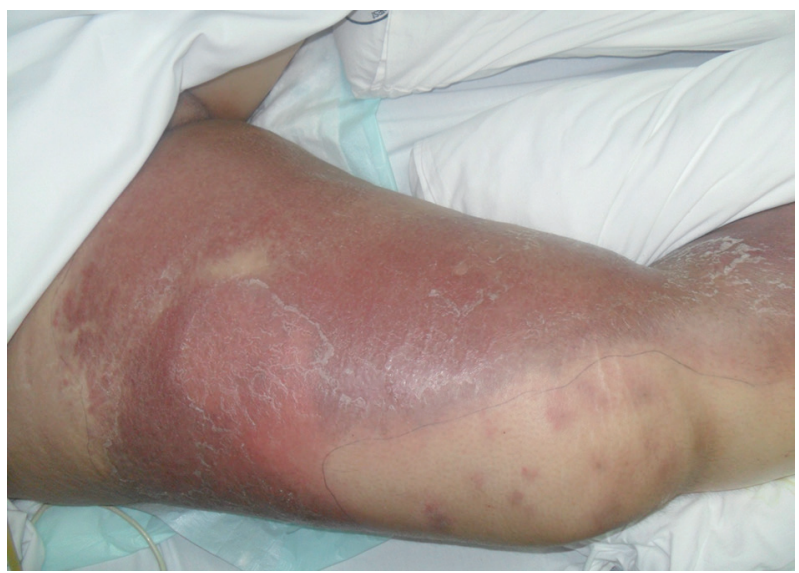

Figure 1. The erythematous, indurated soft tissue lesion on the right thigh.

Blood cultures revealed no bacterial growth. Patient did not respond to antibiotic therapy. Histopathology of the skin biopsy was consistent with diffuse anaplastic large cell lymphoma. Hematology consultation was conducted on the same day of the pathology result and chemotherapy with $\mathrm{CHOP}$ (cy- clophosphamide, adriamycin, vincristine, prednisolone) was initiated. On the fifth day of chemotherapy, the patient became dyspnea and acute signs of disseminated intravascular coagulation (DIC) were emerged. The patient was retrieved to mechanical ventilation with therapeutic and supportive interventions. Despite all measures she did not respond to treatment and unfortunately died on the 10th day of the chemotherapy.

This case was considered noteworthy to be presented with its clinical presentation suggesting complicated erysipelas that has leaded to a delay in the diagnosis and a fatal outcome due to the aggressive clinical course.

Cases with primary cutaneous anaplastic large cell lymphoma, particularly those with an initial presentation of extensive limb disease (ELD), defined as multiple skin tumors in 1 limb or contiguous body regions, have a more aggressive course and may need a more aggressive treatment because of the poorer outcomes. ${ }^{1,2}$

\section{REFERENCES}

1. Woo DK, Jones CR, Vanoli-Storz MN, et al. Prognostic factors in primary cutaneous anaplastic large cell lymphoma: characterization of clinical subset with worse outcome. Arch Dermatol 2009; 145:667-674.

2. Diamantidis MD; Papadopoulos A; Kaiafa G, et al. Differential diagnosis and treatment of primary, cutaneous, anaplastic large cell lymphoma: not always an easy task. Int J Hematol 2009; 90:226-229. 